Research, part of a Special Feature on Cooperation, Local Communities, and Marine Social-ecological Systems: New Findings from Latin America

\title{
Uncommon among the Commons? Disentangling the Sustainability of the Peruvian Anchovy Fishery
}

\author{
Milena Arias Schreiber ${ }^{1}$ and Andrew Halliday ${ }^{2}$
}

ABSTRACT. The term "commons" refers to collectively exploited resources and their systems of usage; a synonymous term is common pool resources. Fisheries are typical common pool resources and also one of the most conspicuous examples of unsustainable use of natural resources. We examine one of the few globally important fisheries that is held to be sustainable, the Peruvian anchovy fishery, and considers the extent to which the institutional characteristics of the fishery conform to design principles that are considered prerequisites for long-term, successful, community-based common pool resources. Results showed that greater conformity to the principles was found in the sustainable phase of the fishery, compared to its unsustainable phase. For this case study, the conditions that supported the transition towards sustainability were: clearly defined resource boundaries, monitoring of rule enforcement, and conflict resolution mechanisms among users and management authorities. On the other hand, clearly defined user boundaries, collective choice arrangements, and nested enterprises were not required to achieve sustainability. The study concludes that the design principles are a valuable tool for analysis and understanding of large-scale common pool resource systems. At the same time it suggests that the application of the principles to a wider range of systems can generate new insights into what is required for successful management of common pool resources.

RESUMEN. Los "bienes comunes" se refieren colectivamente a los recursos explotados y sus sistemas de uso, y también se conocen como recursos de propiedad común (CPR). Los recursos marinos han sido considerados tradicionalmente como CPR y como uno de los ejemplos más conocidos de uso no sostenible de los recursos naturales. Este trabajo examina una de las escasas pesquerías importantes a nivel mundial que se considera sostenible -la pesquería de la Anchoveta peruana (Engraulis ringens), considerando el grado en que las características institucionales de esta pesquería se ajustan a los principios de diseño de gobernanza de recursos comunes que se consideran requisitos previos para el éxito a largo plazo en la gestión de CPR. Los resultados obtenidos mostraron que una mayor observancia y conformidad con los principios de diseño durante la fase sostenible de la pesquería, en comparación con su etapa insostenible. Para este caso de estudio cabe destacar que una clara definición de los límites de uso del recurso, la aplicación de reglas de supervisión y mecanismos de resolución de conflictos entre los usuarios y las autoridades de gestión, han sido todos ellos factores que han apoyado la transición hacia la sostenibilidad de la pesquería. Por otro lado, una clara definición de los límites de uso por parte de los usuarios, la elección de acuerdos colectivos y la unión entre empresas no han sido requisitos para lograr la sostenibilidad de la pesquería. Concluimos que el diseño de principios constituye una valiosa herramienta para el análisis y la comprensión de los grandes sistemas de CPR. Al mismo tiempo, este estudio sugiere que la aplicación de los principios a una gama más amplia de sistemas puede generar nuevos conocimientos que permitirán una gestión exitosa de los CPR.

Key Words: anchovy fishery; common pool resources; design principles; Peru; sustainability anchoveta peruana; recursos comunes; diseño de principios; Perú; sostenibilidad

\section{INTRODUCTION}

Global fisheries are one of the most conspicuous examples of unsustainable use of natural resources. Despite the considerable scientific attention devoted to marine resource management, many of the world's fisheries are still in a deplorable state (Beddington et al. 2007). Nearly one in four fisheries collapsed during the period 1950-2000 (Mullon et al. 2005), where collapse is defined as a $90 \%$ reduction of a wild fish stock. There has been a continuous decline in global catches since the late 1980s (Pauly et al. 2003).

Most wild fisheries are based on the exploitation of common pool resources. Fisheries are a typical common pool resource (Feeny et al. 1990, Neiland 2006, Cox et al. 2010), showing the attributes of costly exclusion of potential users and substractability, i.e., when exploitation by one user reduces the resource availability for others (Ostrom et al. 1999). This paper examines one of the few globally important fisheries that is held to be sustainable, the Peruvian anchovy fishery (Mondoux et al. 2008), and considers the extent to which the institutional characteristics of the fishery conform to principles that are considered prerequisites for the sustainability of common pool resources.

Until the 1980s, research into common pool resources was under the sway of the paradigm of the "tragedy of the commons". This holds that multiple individuals, acting independently, and rationally consulting their own self- 
interest, will ultimately deplete a shared limited resource even when it is clear that this is not in anyone's long-term interest (Hardin 1968). However, from the mid 1980s, this view was increasingly challenged. Evidence that some common pool resource systems were robust over long periods of time while others failed stimulated the search to identify the features that distinguished successful from unsuccessful efforts (Ostrom 1990).

In 1990, Elinor Ostrom proposed a set of eight "design principles" of common pool resources management regimes that are long-lasting (Ostrom 1990); these are "general institutional regularities" that can be observed among common pool resource systems "that were sustained over a long period of time" (Ostrom 2009a). Since then, the validity of these principles has been the subject of intense scrutiny, both from a theoretical and an empirical perspective (Ostrom 2009a, Cox et al. 2010). In a review of 91 studies, Cox et al. (2010) found that empirical evidence was broadly supportive of the principles. Some minor modifications to the principles were also proposed as a result of the review (see Table 4 in Cox et al. 2010). However, empirical evidence considered to date relates almost exclusively to small-scale common pool resource systems, where the "community of users" is often a local community such as a village or a cooperative. Cox et al. (2010) conclude "we remain uncertain as to whether the principles may apply to systems at a variety of scales".

Thus there is clearly the need for empirical studies to assess the extent to which the design principles are applicable to large-scale common pool resource systems. The Peruvian anchovy provides an excellent opportunity to do so. Firstly, it is undeniably a large scale enterprise. This fishery represents almost $10 \%$ of worldwide marine fisheries landings (FAO 2010) and has been described as the largest monospecific fishery that has ever existed on Earth (Bakun and Weeks 2008, Aranda 2009b). Anchovy fishing takes place over an area of approximately $14,000 \mathrm{~km}^{2}$ in the coastal waters of north and central Peru between $4^{\circ}$ and $15^{\circ} \mathrm{S}$, where around 1300 purse seiners target only one fish species: the Peruvian anchovy Engraulis ringens. Secondly, the social and institutional characteristics of the fishery are clearly distinct from those of more widely studied small-scale common pool resource systems. The "community of users" consists not of village residents but of wealthy capitalists who have direct access to the highest levels of government and operate out of fortified compounds equipped with state-of-the-art manufacturing and communications technology. The link to local livelihoods that is considered a key feature of sustainable small-scale common pool resource systems (Cox et al. 2010) is entirely lacking: 99\% of anchovy catches are converted to fishmeal in Peru to be exported to international markets for aquaculture and animal food. Thirdly, the fishery is currently considered to be sustainable. Indeed it has been described as the most intense and successful fishery worldwide (Chavez et al. 2008), and was recently placed first in a report ranking 53 marine countries by the sustainability of their fisheries (Mondoux et al. 2008).

Table 1. Design principles of robust, long-term, common pool resources during the unsustainable growth phase (1960-1972) and the sustainable phase (1994-2009) of the Peruvian anchovy fishery.

\begin{tabular}{|c|c|c|}
\hline Design principle & $\begin{array}{l}\text { Unsustainable } \\
\text { phase }\end{array}$ & $\begin{array}{l}\text { Sustainable } \\
\text { phase }\end{array}$ \\
\hline \multicolumn{3}{|l|}{ Clearly defined } \\
\hline User boundaries & No & $\mathrm{No}^{\dagger}$ \\
\hline Resource boundaries & No & Yes \\
\hline \multicolumn{3}{|l|}{ Congruence } \\
\hline Between rules and local conditions & Yes & Yes \\
\hline $\begin{array}{l}\text { Proportional equivalence between costs } \\
\text { and benefits }\end{array}$ & Yes & Yes \\
\hline Collective choice arrangements & No & No \\
\hline \multicolumn{3}{|l|}{ Monitoring } \\
\hline Rule enforcement & No & $\mathrm{Yes}^{\ddagger}$ \\
\hline Resources & Yes & Yes \\
\hline Graduated sanctions & No & Yes \\
\hline \multicolumn{3}{|l|}{ Conflict resolution mechanisms } \\
\hline Among users & Yes & Yes \\
\hline Among users and management authorities & No & Yes \\
\hline Minimal recognition of rights to organize & Yes & Yes \\
\hline \multicolumn{3}{|l|}{ Nested enterprises } \\
\hline Users & Yes & Yes \\
\hline Management authorities & No & No \\
\hline \multicolumn{3}{|c|}{$\begin{array}{l}\text { Only at national levels, i.e., if foreign multinational or only national } \\
\text { companies are allowed to participate in the fishery. (For details see Arias } \\
\text { Schreiber 2012.) } \\
\text { Since } 2003 \text {. }\end{array}$} \\
\hline
\end{tabular}

Finally, the fishery has not always been set on a sustainable landings course, and various different phases of the fishery can be identified for the purposes of comparative analysis. Based on landings statistics, four distinct phases of the Peruvian anchovy fishery can be identified (Arias Schreiber 2012). Following its establishment in the mid 1950s, the anchovy fishery soon entered a phase of explosive and uncontrolled growth, which by the end of the 1960 s was clearly unsustainable. This "unsustainable growth phase" culminated in a collapse in 1972, triggered by the extreme El Niño event of 1972-73. After the collapse, a second phase from 1973 to 1984 was characterized by unfavorable oceanic conditions for anchovies and low catches. A third phase, from 1985 to the present, can be further divided into a second growth period from 1985 to 1993 and a sustainable landings period from 1994 to the present (Fig. 1). During the sustainable phase annual anchovy catches have stabilized at between 5 and 9 million tonnes in years with propitious oceanographic conditions, and have recovered quickly from perturbations caused by climatic variations, including the extreme El Niño event of 1997-98 (Arias Schreiber 2012). In 2009 a new management system for the fishery was introduced, based on quotas for individual fishing vessels, which substantially 
altered some key, long-standing, institutional features of the fishery (Aranda 2009a, Arias Schreiber 2012). In institutional terms, this represents the beginning of a further new phase for the fishery, although it is too early to assess its impacts, if any, on the sustainability of landings.

This article reviews the design principles proposed by Ostrom (1990), as modified by Cox et al. (2010), for the successful long-term management of common pool resources in the light of experiences during both the unsustainable and sustainable phases of the Peruvian anchovy fishery. Specifically, we address the following questions: (1) whether the design principles can explain the recent sustainability of the fishery; (2) whether institutional differences between the unsustainable and sustainable phases of the fishery provide evidence to support the design principles; and (3) whether the Peruvian experience suggests further modifications to the design principles that would enhance their applicability to large-scale common pool resources.

Fig. 1. Historical Peruvian anchovy landing, major El Niño events, and phases of the fishery.

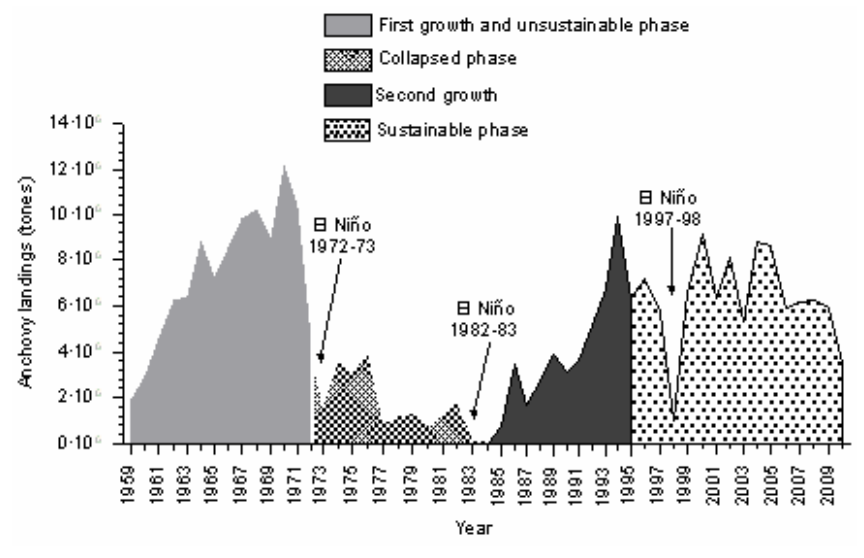

\section{METHODS}

This article is the result of semistructured interviews carried out at Peruvian fishery institutions between October and November 2009. Ten key informants were interviewed at the Vice-Ministry of Fisheries, eight from the Peruvian Marine Research Institute (IMARPE), and nine from the private fishery sector. Interviewees were selected on the basis of length of experience and period of time in post, in order to obtain as much information as possible from the beginning of the fishery to the present (see list of interviewees in Appendix 1). Three interviewees had been involved with the anchovy fishery since the 1960s (two from IMARPE and one from the industry), two since the 1970s, ten since the 1980s, five since the 1990s and seven since the start of this century. The article also draws on the experience of the first author as a scientific officer at IMARPE from 1994 to 2001. The questionnaire used during the interviews is shown in Appendix 2.

Interviews were triangulated with intensive documentary analysis from published material and other sources including internal reports, yearbooks, fishery magazines, and legal databases. Historical statistical data including anchovy landings, number of fishing vessels, fishing effort expressed in fishing days per year, fishmeal prices, and anchovy exports were obtained from the Pelagic Resources Department of IMARPE.

\section{RESULTS}

The compliance by the Peruvian anchovy fishery with Ostrom's design principles for long-lasting governance regimes of common pool resources (as modified by Cox et al. 2010) across the sustainable and unsustainable phases of the fishery is shown in Table 1.

\section{Principle one: clearly defined boundaries}

This principle contains two components: 1A User Boundaries, understood as clear boundaries between legitimate users and nonusers, and $1 B$ Resource Boundaries, i.e., boundaries that define the resource system and separate it from the larger biophysical environment (see Table 4 in Cox et al. 2010). In summary, user boundaries of the Peruvian anchovy fishery have been permeable, although perhaps decreasingly so in recent years; resource boundaries have been increasingly clearly defined.

In relation to user boundaries, exclusion of outsiders in marine fisheries is difficult to achieve and this fishery has been no exception. However, different conditions have governed entry into the two activities that make up the Peruvian anchovy fishery: fishing and processing. Within the community of users, two distinct groups can be recognized: firstly the large fishing companies, which operate the processing plants and also own fishing fleets that directly supply these plants; and secondly, independent boat owners who sell anchovy to the processing plants under informal contracts. Along the history of the fishery, there has been no effective limitation on access to the fishery resource. As a consequence, the number of fishing vessels in this fishery has broadly followed changes in the abundances of anchovies rather than being a response to management regulations to exclude outsiders (Fig. 2). Entry to the processing industry has followed the same dynamics, leading to a historical overcapitalization of both fishing vessels and processing factories (Ibarra et al. 2000, Thorpe et al. 2000, Fréon et al. 2008, Aranda 2009a). In both sectors, the response to the problem of "free riders" has been to incorporate them into the formal sector, rather than to attempt to enforce exclusion. 
Although attempts were made to limit access to the fishery through a system of fishing licenses as early as 1956, these served only to increase corruption and speculation and the system was abandoned in 1962 (Thorp and Bertran 1978). Thus, during the unsustainable phase, any person with enough financial capital to build and put a fishing vessel to sea was allowed to do so. The availability of apparently inexhaustible stocks of anchovy fuelled a frenzy of shipbuilding that persisted throughout the 1960s and early 1970s (Aranda $2009 b$ ). Vessels were constructed, with or without qualified labor, in empty lots and in the streets of Callao, Peru's major port (Roemer 1970). Expansion was further fuelled by foreign investment. Capital assets in the fishery coming from foreign companies increased from 12\% in 1960 to more than $40 \%$ in 1967 (Thorp and Bertran 1978). The size of the fleet increased spectacularly from 52 registered vessels in 1953 to 1309 in 1972, although even this was down from the maximum of 1744 boats in 1964 (Aranda 2009b).

Fig. 2. Historical evolution of Peruvian anchovy landings, anchovy fishing vessels, and fishmeal factories between 1960 and 2008. Anchovy landings (shaded area) correspond to landings presented in Fig. 1.

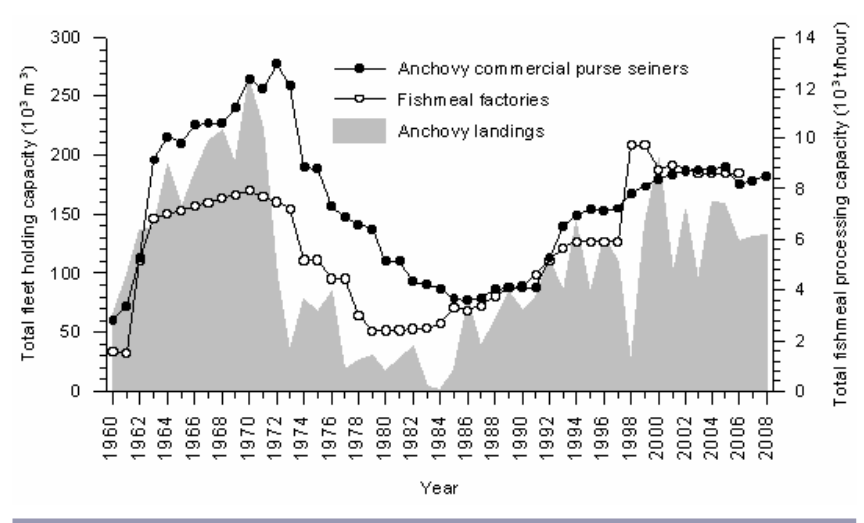

Subsequent efforts, to set limits on the number of vessels and processing plants also had limited success in avoiding a de facto open access fishery (Thorpe et al. 2000). Following the collapse of the fishery in 1972, the anchovy fishing fleet was nationalized and large numbers of vessels were decommissioned. However the fishery was returned to private ownership just four years later. The number of fishing vessels grew moderately during the sustainable period and the fleet's total holding capacity increased from around $150,000 \mathrm{~m}^{3}$ in 1994 to $220,000 \mathrm{~m}^{3}$ in 2008 . This increase was partially a consequence of a measure (Law 26920; Congreso de la República del Perú 1998) by which wooden vessels with holding capacities between 30 and 110 tonnes were officially recognized as part of the anchovy fishing fleet from January 1998 (Aranda 2009b). This incorporated an important group of 'free-riders' into the formal fishery, by legalizing the activities of the small-scale fleet which, before then, had been fishing anchovy illegally (Bermejo 2004).

During the unsustainable phase, user boundaries to the processing industry were indirectly restricted by market forces. A sharp decline in fishmeal prices in 1959-60, due to excessive supply of fishmeal on the international market, prompted the private sectors of the principal fishmealproducing countries to establish an international arrangement aimed at stabilizing the market, which is known as the "Paris Agreement" (Roemer 1970). This established national quotas for fishmeal sales, which were to be organized through export licenses for fishing companies issued by the respective governments (Hammergren 1981). The Peruvian government recognized fishing companies associated under the National Fisheries Society (Sociedad Nacional de Pesquería, SNP), and Supreme Decree 18 empowers this organization to act as the government's agent in assigning export licenses in conformity with world market quotas ("Perú ratifica ..." 1961). Within the SNP, the Peruvian Fishing Consortium was established for this purpose. However, between 1961 and 1963 export quotas for Peruvian fishmeal were regularly exceeded (Roemer 1970) due to the activities of unassociated fishing companies, which accounted for between 15 and $20 \%$ of the total ("Número equivocado ..." 1962a). These "free riders" took advantage of improved prices to sell their fishmeal through channels that bypassed the Consortium. In response, the Peruvian government required every company, by Law-Decree 14228, to join the Consortium as the only channel for export of fishmeal from Peru ("Número equivocado ..." 1962a). After 1963, international fishmeal prices stabilized and the country quota system was soon abandoned. However, the Consortium continued in exclusive charge of Peruvian fishmeal marketing until 1966, when three other organizations were also legally permitted to engage in marketing (Roemer 1970, Hammergren 1981).

Since then, in practice, entry into the processing industry has been limited by the ongoing consolidation process in this fishery sector (Garcia 2007) that has led to the current situation where seven large companies own more than $50 \%$ of fishing vessels' holding capacity and at least 50\% (72 units) of the processing factories (Bendezú 2008).

The boundaries of the resource, i.e., the anchovy stock, have been progressively defined since 1970 , when the first tagging experiments were carried out by IMARPE to determine the habitat and distribution of this resource ("Marcación ..." 1970a). Since 1973, two anchovy populations units have been recognized off Peru: the north central stock from $04^{\circ} 30^{\prime}$ to $15^{\circ} \mathrm{S}$, and the southern stock from $15^{\circ} \mathrm{S}$ to the southern limit of the Peruvian maritime domain. To the west, anchovy populations extend up to $100 \mathrm{~nm}$ offshore (Checkley et al. 2009). Since Chile, Peru, and Ecuador declared their respective $200 \mathrm{~nm}$ Exclusive Economic Zones (EEZ) as early 
as 1953, the north central stock is defined by natural boundaries and is contained entirely within Peruvian waters. Under normal oceanographic conditions, fishing targets this stock, which is also by far the most productive (Barange et al. 2009). The southern stock, by contrast, is defined partly by natural and partly by political boundaries, i.e., the maritime border with Chile. Catch quotas and closed seasons have been given separately for each population stock since 1983 (Ganoza et al. 2000).

\section{Principle two: congruence}

Congruence refers to the harmonious fit between rules for resource use and local conditions-cultural or ecological. This principle also contains two components: $2 A$ Congruence with local conditions, in the sense that appropriation and provision rules are congruent with local social and environmental conditions, and $2 B$ Proportional equivalence between costs and benefits, the former being determined by provision rules and the latter by appropriation rules. The Peruvian anchovy fishery has complied, since its inception, with the principle of congruence in both senses of the term.

Congruence between rules and local environmental conditions of the resource has always been an important feature of the Peruvian anchovy fishery. The first closed season was declared by ministerial resolution in 1965 and lasted for one month ("Agosto ..." 1965), i.e., during the spawning peak of the anchovy population (Checkley et al. 2009). Simultaneously, measures were taken to prohibit the landing of catches if $50 \%$ or more of the catch consisted of fish of $12 \mathrm{~cm}$ or less, and a ban on weekend fishing was introduced. In 1966 the closed season was extended to three consecutive months from June to August (Tsukayama and Palomares 1987). In 1967 the government imposed another 6-week closed season during the height of the fishing season in February and March (Roemer 1970) with the aim of protecting juvenile anchovy in the recruitment phase. In these years, catch quota limits were also imposed, with annual limits of between 8 and 9 million tonnes, in line with IMARPE's assessments of sustainable yields (Clark 1976, Chavez et al. 2008). These practices have continued in the sustainable phase. In general management measures, such as the closure of the fishery or quota regulations, are adjusted on an ad hoc basis in response to information from monitoring data and recommendations from IMARPE. Since 1994, any management measure has had to be backed up by a written recommendation from IMARPE. Agreement exists between scientists and politicians that dynamic changes in anchovy stocks call for an equally dynamic response. A recommendation by IMARPE, for example to suspend fishing at one or more ports, can be implemented in a matter of days (Arias Schreiber et al. 2011). Moreover, numbers of ministerial resolutions enacted to regulate the fishery tend to increase during El Niño events, which initiate periods of stress and instability for the resource, providing evidence of adaptive governance capacity in response to local environmental conditions (Arias Schreiber 2012).

Congruence between costs and benefits for resource users during both phases of the fishery has been always high since taxes, fishing licenses, and funds to cover management, monitoring, and scientific research have generally been calculated based on tonnes of landed anchovy, or tonnes of fishmeal exported. As an example, Law-Decree 14265 of December 1962 established a tax of 25 Peruvian Soles (around US\$1)/t of anchovy landed ("Regalo de Pascua ..." 1962b). The same principle is used nowadays, for example to calculate the cost of fishing rights. According to Supreme Decree 024-2006-PRODUCE of November 2006 (Gobierno del Perú, Ministerio de la Producción 2006a), fishing rights are valued at $0.25 \%$ of the export FOB price of fishmeal per tonne of anchovy landed. These straightforward practices have enabled the fishery to maintain the equivalence between costs and benefits in a way that can be perceived to be fair by the resource users.

\section{Principle three: collective choice arrangements}

Collective choice arrangements authorize resource users to participate in making and modifying their rules. The extent to which this principle has applied to the Peruvian anchovy fishery is open to interpretation.

Collective choice arrangements are considered to favor effective resource management by drawing on local knowledge of the resource. In the context of the Peruvian anchovy fishery, "local" has a somewhat different meaning and a national organization, the SNP, has been the principal channel for user participation in decision making. The SNP was created in 1952 as a nonprofit civil cooperative association. During the 1960s, it engaged in intensive lobbying on behalf of the industry around the two major areas of dispute between the government and the fishing companies: taxation and credit policy (Hammergren 1981). It exerted considerable political influence over the development of the anchovy fishery during the 1970s (Caravedo 1979), and this influence has continued during the sustainable phase, although more subtly.

The SNP defines itself as a civil association representing the Peruvian private fishery sector and counts on around $70 \%$ of the anchovy fishing companies being among its members. However, in practice, the SNP provides limited representation of users in rule making. It does not represent independent boat owners, who are grouped in other associations. Moreover, the way the SNP functions excludes most members from participating in modifying the operational rules. Decisions inside the SNP are based on a proportional voting system, in which the number of votes per fishing company depends on its fishmeal production in the previous 15 months (Roemer 1970). This voting system invests decision-making power in a small number of large companies. The influence of these 
powerful companies is further increased by the existence of informal networks that provide close links between them and key personnel in government decision-making agencies (see Principle seven below).

\section{Principle four: monitoring}

This principle contains two components: $4 A$ Monitoring to ensure rule enforcement, and $4 B$ Monitoring the resource. In summary, monitoring of both rule compliance and resources has become more extensive, intensive, and effective during the sustainable phase, compared to the unsustainable phase.

With regard to rule enforcement, during the unsustainable phase monitoring of landings was undertaken by personnel from IMARPE who had no authority to enforce compliance. Resources were inadequate to monitor the large number of vessels involved and the high number of permitted fishing days, i.e., on average 223 days/year (Fig. 3). Controlling fishermen's behavior was also difficult, because tracking technology to follow fishermen at sea was not available and monitoring of landings was ineffective, resulting in an underestimation of at least $20 \%$ in official landings statistics for the period 1952 to 1982 (Castillo and Mendo 1987).

Fig. 3. Annual number of anchovy fishing days and value of Peruvian fishmeal exports, 1959-2008.

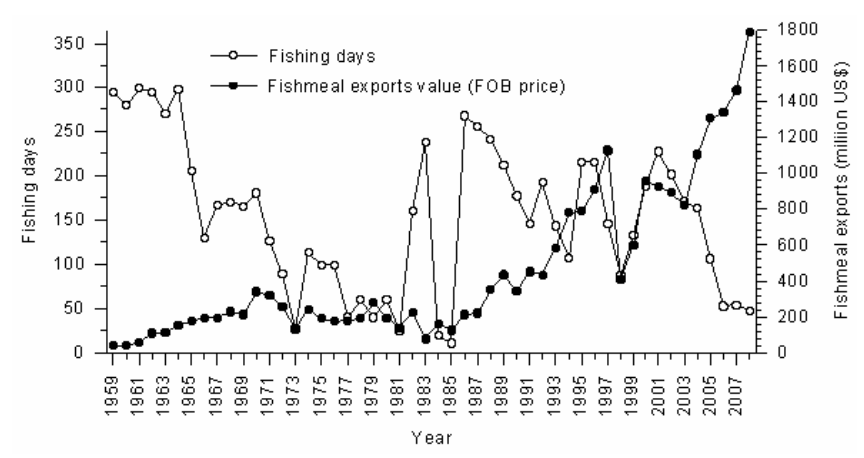

Following the establishment of the Ministry of Fisheries in 1970, a Department for Monitoring, Control, and Surveillance was set up; however, the lack of proper financial support and appropriate technology resulted in poor performance. In the sustainable phase of the fishery, the number of vessels was somewhat reduced, and the average annual number of fishing days was also reduced to 141 days (Fig. 3). However, monitoring such a large industry still posed considerable challenges, and in response to these challenges new regulations were introduced to facilitate monitoring and reduce costs. Since 1999, each fishing vessel has been obliged to pay fishing rights ("derechos de pesca") equivalent to around US\$3/t of anchovy landed. The funds generated are used to finance the operation of the Vice-Ministry of Fisheries and its associated institutions, including IMARPE. Sanctions for nonpayment include the confiscation of the fishing license. In addition, the use of Vessel Monitoring System with satellite tracking systems in each fishing vessel has been required by law since 2000 (Supreme Decree 001-2000-PE; Gobierno del Perú, Ministerio de Pesquería, 2000); costs (around US\$200 monthly for equipment and services) are covered by the ship owners. Likewise, landings at all ports are simultaneously monitored by IMARPE and inspectors from the Fishing and Landing Monitoring and Surveillance Program. This program, launched in 2003, transferred surveillance of compliance with anchovy fishery regulations to an independent international company financed by the fishing companies. Annual costs of the program are capped at US\$7 million, and these funds are raised by a levy of US $\$ 1.40 / t$ of landed anchovy. The Swiss company Société Générale de Surveillance (SGS) and a Peruvian company Certificaciones del Perú (CERPER) are currently employed to undertake this independent monitoring.

Monitoring of the anchovy population (resources) started as early as the end of the 1950s (Castillo and Mendo 1987) and intensified after 1960 with the establishment of the Peruvian Research Institute for Marine Resources, which in 1964 was renamed IMARPE (Barange et al. 2009). Collection of anchovy landing data started in 1959 (Doucet et al. 1962), and collection of size structure data of landed fish started in 1961 (IMARPE 1965). In 1966, in response to the high costs involved in monitoring the resource at sea, IMARPE initiated the so-called Eureka cruises (Arias Schreiber et al. 2011). These were established by legal agreements by which the fishing companies allowed IMARPE to use their fleet as scientific vessels in order to monitor anchovy populations in real time (Barange et al. 2009). Scientific and technical personnel from IMARPE were sent to the main fishing ports, from where anchovy fishing vessels set sail, to perform experimental fishing and oceanographic sampling. The fishing companies involved were allowed to process the anchovy catches to recover some of the associated financial costs (Arias Schreiber et al. 2011).

During the 1970s, new acoustic techniques were developed based on echo-integration of data from digital echosounders to estimate fish populations. Since 1982, the Peruvian government via IMARPE has monitored anchovy populations using these techniques through twice-yearly hydro-acoustical cruises along the geographical range of the anchovy population (Ganoza et al. 2000). The results of these cruises are used to calculate the catch quotas for the two annual anchovy fishing seasons. Thus the adoption of new technology has made monitoring relatively easier during the current, sustainable phase of the fishery. Current annual expenses of IMARPE are around US\$15 million (De La Puente et al. 2011), from which about $60 \%$ is used to monitor anchovy populations (M. Ñiquen, personal communication). However these apparently very high monitoring costs represent less than $1 \%$ 
of annual export values of the anchovy industry, which are estimated at US\$1000 to 1500 million over the last decade (Fig. 3).

\section{Principle five: graduated sanctions}

Effective graduated sanctions are seen as a mechanism for ensuring rule compliance by ensuring transparency and building trust between resource users (Ostrom 2009a). Sanctions were not applied during the unsustainable phase of the Peruvian anchovy fishery. In the sustainable phase, graduated sanctions have been introduced, but their application has been only partially effective.

Sanctions were neither clearly identified nor enforced during the unsustainable phase of the fishery. By-laws of the First Peruvian Fisheries Act from 1971 (Gobierno del Perú 1971a) established graduated sanctions for different fishing infractions for the first time; these ranged from fines between 1000 and 1 million Peruvian Soles, to the permanent confiscation of fishing licenses (Supreme Decree 011-71-PE, Art. 273; Gobierno del Perú 1971b). More recently, in the sustainable phase of the fishery, legal sanctions have been imposed according to: (1) the type or nature of infraction, (2) the offender's intention, (3) the degree of damage caused to the marine environment or amount of benefits illegally obtained, and (4) records of previous offenses (Supreme Decree 012-2001-PE, Art. 149; Gobierno del Perú, Ministerio de Pesquería 2001). However, even with legally graduated sanctions during the sustainable phase, users in this period regularly avoided being sanctioned by appealing sentences and transferring their cases to the Peruvian judicial system where corruption is still quite widespread (De La Puente et al. 2011). In 2008, five judges were removed from their positions for having allocated illegal fishing licenses (R. Rey; quoted in Gobierno del Perú, Ministerio de la Producción 2008).

\section{Principle six: conflict resolution mechanisms}

Management of common pool resources is considered to be an inherently conflictive activity; rapid, low-cost local arenas for resolution of conflicts among users are necessary to prevent conflicts from spiraling out of control (Ostrom 2009a). Moreover successful resolution of conflicts can spark learning and change (Dietz et al. 2003). In the Peruvian anchovy fishery, formal arenas for resolving conflict have long existed, and these have further developed in the sustainable period.

Since 1952, the SNP has been the institution responsible for providing facilities for resolution of conflicts between resource users. Procedures for resolving conflicts between users and government agencies have been available since the establishment of the Ministry of Fisheries in 1970. By contrast, they were absent during the unsustainable period. Throughout the 1960s, government decisions affecting the fishing sector were made by a variety of agencies for which fishing policy was not a primary concern (Hammergren 1981). Consequently the most important decisions affecting the fishery were not made by any of these agencies, but came out of the Ministry of Finance and the Congress. As a result, resolution mechanisms were difficult to implement when conflicts of interest arose.

Since the Ministry of Fisheries was set up in 1970, it has been the practice of the Peruvian government and diverse members of the fishing sector to establish so-called "Sectorial Working Commissions" to discuss and give advice to the authorities when conflicts arise or the fishery enters a crisis period, i.e., during extreme El Niño conditions. For example, by Supreme Resolution 005-70-PE-ODP of February 1970, the Ministry of Fisheries set up a Commission to perform a feasibility study for the establishment of a quota system for the supply of anchovy to processing factories ("Comisión estudiara ..." $1970 b$ ). The Commission, composed of members of the Ministries of Fisheries and the Treasury, and one member of the SNP, had one month to present its results. A similar commission was set up in 2006 to evaluate the problem of overcapacity of the anchovy fishing fleet (Ministerial Resolution 215-2006-PRODUCE; Gobierno del Perú, Ministerio de la Producción 2006b). Although the impact of such commissions in the decision-making process is varied, these practices could have reinforced networking and learning processes, particularly during the sustainable phase.

\section{Principle seven: minimal recognition of rights to organize}

This principle refers to rights, granted by governments to resource users, to organize to manage the resource independently of government (Cox et al. 2010). It appears to presuppose a conflict of interest, or at least of perspective, between local users and external government agencies operating at a larger scale. These conditions apply only partially to the Peruvian anchovy fishery, which operates at a national level-the same as government-and where the dividing line between government and resource users has sometimes become blurred.

The organization of users of the anchovy fishery under the auspices of the SNP has always been recognized by Peruvian authorities. Indeed, the government's official recognition of the Society as being responsible for setting fishmeal export quotas in the 1960s has even been described as a delegation of the state's policy-making functions to the fishing companies (Hammergren 1981). As mentioned above, throughout the sustainable period, intensive lobbying by the SNP has continued. The SNP does not have an official role in deciding on rules for the management of the fishery. However, one of the seven members of IMARPE's Board of Directors is by law a representative of the Society, and there is also one member of the SNP in the governmental Committee for Monitoring the Fishing and Landing Surveillance Program. The real influence of the SNP is greater than this modest official representation suggests, and over the years numerous directive personnel at 
IMARPE and the Fisheries Ministry, up to the highest level, have been selected because of their strong relations to the SNP. This influence can be seen in specific policy decisions, such as the establishment of the Individual Quota System in 2008, which has been widely attributed to be a response of the Society's demands.

\section{Principle eight: nested enterprises}

This design principle relates to the arrangement of governance activities in multiple layers of small-scale organizations nested in ever larger organizations. The reliance of the Peruvian anchovy industry on industrial-scale fish processing means that it is an inherently large-scale enterprise. Moreover, as users are private companies, the dominant paradigm is of competition on the market rather than cooperation. Thus the opportunities for nesting are limited.

In the unsustainable phase, fishing companies were associated only within the SNP, which comprised around $60 \%$ of users and which in 1960 became a member of the International Fishmeal and Fish oil Organization (IFFO). During the sustainable phase, there has been some "nesting" at larger scales: fishing companies associated in the SNP are also part of the Peruvian Exporters Association (ADEX) and the Peruvian National Confederation of Private Business Associations (CONFIEP) which is member of the International Organization of Employers (IOE). The management organization, the Ministry of Fisheries, has been a single and centralized institution since its establishment in 1971. This situation has continued throughout the sustainable phase, although formally, since 2001, the Vice-Ministry of Fisheries has operated as one of the two divisions within Ministry of Production. Although the Peruvian government has undergone a process of decentralization since 2002 and Regional Fishery Directorates have been established, with some role in the management of other fisheries, anchovy fisheries management remains the sole responsibility of the central Vice-Ministry of Fisheries.

\section{DISCUSSION}

Although the conditions and principles for long-lasting, successful, common pool resources, as described by Ostrom, have been mainly applied to management undertaken by traditional communities with almost no intervention from the government, they offer an excellent point of departure for analysis of institutional settings of larger common pool resource systems and, specifically, commercial fisheries. This is confirmed by the results of our study, which demonstrate that the design principles can be usefully applied to inform the analysis of a large-scale common pool resource. Most of the principles were found to be relevant for a study of the Peruvian anchovy fishery. Moreover, the validity of the principles as indicators of the sustainability of common pool resource management is at least partially confirmed by the fact that greater conformity to the principles was found in the sustainable phase of the fishery, compared to the unsustainable phase (Table 1).

It is recognized that the principles do not offer a recipe for success and cannot be applied in a mechanical way (Ostrom et al. 1999, Bruns 2007, Ostrom 2009b). Like previous empirical studies (Cox et al., 2010), this one has suggested some ways in which the principles could be modified or expanded. Our study suggests that controls on catches can be an effective alternative to restricting the number of users. A dynamic decision-making system is necessary to respond effectively to variations in resource availability. Finally, management rules need to be adapted to the specific biological characteristics of the resource being managed. On the other hand, the design principles alone are insufficient for analysis of the rich experience of more than half a century of common pool resources considered in this study. At times it was difficult to constrain our account within the (self-imposed) analytical structure, based around "testing the design principles".

One of the main challenges in applying the design principles to asses our case study fishery was the difficulty of showing causality between institutional characteristics and the sustainability of resource use. While the design principles suggest a set of institutional features that favor sustainability, they do not provide a procedure for analyzing their role within the wider, complex social-ecological system. Specifically they do not take explicit account of the role played by the physical and ecological settings, and/or distinctive characteristics of the resource involved. A number of commentators have signaled the need to give more consideration to the properties of the resource itself (Cox et al. 2010). This certainly applies in our case, given that Peruvian anchovy stock fluctuations, like other pelagic fish stocks, are highly driven by environmental oceanographic conditions. In addition to improved management institutions, the phase of sustainable landings of the fishery has also coincided with medium-term favorable oceanographic conditions for anchovy stocks. Furthermore, a natural resource may be inherently more or less susceptible to sustainable use. The Peruvian anchovy, as an abundant, fast-breeding, and highly mobile species, adapted to living in a highly unpredictable biophysical environment, might appear to be innately resilient to bad management, particularly as alternative resources, such as sardine and other pelagic fish, are often available to sustain the fishing industry when anchovy stocks are low.

Our results showed that for this case study, clearly defined user boundaries, collective choice arrangements, and nested enterprises were not required to achieve sustainability. It can be argued here that the choice of the Peruvian government has been to relax user boundaries while clearly defining the amount of resources that the users are allowed to withdraw. This has been achieved through a quota system that guarantees the natural replenishment of the resource. Catch quotas that 
were not complied with during the unsustainable phase, are currently enforced by not only closing the fishing season when the quota is attained but also by simultaneously banning fishmeal processing. The clearly identifiable smell of burning fish, detectable even some miles away from the factories, makes it impossible for illegal fishmeal reduction to go unnoticed, and supports compliance (Arias Schreiber 2012).

A criticism that has been made of the design principles from the perspective of community-based management of common pool resources is that they appear, incorrectly, to assume resource users are "coherent wholes without internal conflict or heterogeneity" (Cox et al. 2010). This study provides evidence that this criticism is also valid at larger scales. In the Peruvian anchovy fishery, power relations among the resource users are important and arguably play a key role in determining patterns of resource use. Regarding collective choice arrangements, it is probably not surprising that for common pool resources at larger scales, the right to define and modify rules is limited to the most important and powerful users. The anchovy fishery represents at least $7 \%$ of Peru's total foreign exchange earnings; and in 2010 fishmeal and fish oil exports reached 1 million tonnes, valued at US\$1.9 billion (SNP 2010). In this context is it hardly surprising that government fishing policies are respectful of the fishing industry elite's demands, and pay less regard to internal power relations and potential conflicts with other users.

The experience of the Peruvian anchovy fishery also confirms the importance of "fit" between administrative boundaries of a common pool resource system and natural ecological boundaries. Peruvian authorities have had a greater degree of control over the north central stock, which is wholly within Peruvian waters, than over the southern stock, which is shared with Chile. For example, closed seasons for the southern anchovy stock implemented in Peru have not been reciprocated by Chilean authorities, leading to complaints by Peruvian fishermen that they were "leaving the anchovies in the water for the Chileans to catch". Consequently, although some efforts have been made in the past to coordinate the management the southern anchovy stock in cooperation with Chilean authorities, usually no catch quota is applied and the fishing season is open all year around (Arias Schreiber 2012). This is a further dimension of "congruence" whose importance has been noted by other authors (Hanna et al. 1995, Anderies et al. 2004), but not explicitly recognized in the design principles as currently formulated.

It can be argued that a further feature of the Peruvian anchovy fishery favoring its persistence has been the speed of decision making based on intense resource monitoring. Speed and flexibility of responses to changing conditions are likely to be key attributes of sustainable systems for managing common pool resources, particularly when the resource itself is inherently dynamic and unpredictable as in the case of the
Peruvian anchovy. On the other hand, when monitoring results are not regarded as legitimate, or are not transmitted to management authorities in a timely manner, this can hinder the fishery's sustainability. Waters in northern Peru are perhaps the best-monitored large ecosystem in the world, allowing for unusually effective management of fisheries in spite of internal (economic) and external (environmental) challenges (Chavez et al. 2008). It is probably the only place in the world were management authorities are informed on fishing landings on a daily basis (M. Espino, personal communication) and where management decisions have, by law, to be backed up by a scientific report.

On the other hand, rapid decision making is inevitably "topdown" in nature, so this might well contradict the principle of "collective choice agreements", as it is generally understood, at least in specific instances. This highlights the fact that not all the principles have to be complied with for common pool resource management to be successful. It also suggests that compliance with the principles might be achieved through a number of possibly quite different institutional arrangements. As mentioned before, in the Peruvian case, a notable feature of collective choice arrangements was the dominance of powerful stakeholders within the user group, with close links with officials who were invested with decision-making capacity in the responsible government agencies. This raises the interesting question of whether this kind of "top-down" decision making could also provide a viable model at a community level.

External markets have been identified as another key driver of change in common pool resource systems. The demand for products from common pool resource systems and how resource users respond to this demand can be expected to have large impacts on determining patterns of resource use. Market forces are often considered as a destabilizing influence when they affect hitherto self-sufficient community-based common pool resource systems (Cox et al. 2010). Relations between the Peruvian anchovy fishery and the global market for fishmeal are complex and suggest that such clear-cut conclusions regarding the role of market forces are not applicable in this case (Arias Schreiber et al. 2011). However, this is also outside the scope of the present study.

Coming back to our initial question: is the case of the Peruvian anchovy fishery "uncommon" among "the commons"? The answer is no. The history of this fishery tells us that lack of proper institutions, including regulations, results in overexploitation and collapse. However, as in Ostrom's cases, the history of this fishery (until now) has not ended up in a "tragedy". Our results show that Ostrom's eight design principles only partially explain the success of the anchovy fishery. This result is perhaps not unexpected, given that this study was dealing with a large-scale fishery governed at the national level. At this level, scientifically recognized and 
controlled boundaries of resource use, congruence or institutional fit with ecological and cultural conditions, managed participation, careful monitoring, and frequent interaction between resource users and governmental management authorities can be considered as key principles of sustainable common pool resource systems.

The study of the Peruvian anchovy fishery confirms the design principles as a valuable tool for analysis and understanding of large-scale common pool resource systems. At the same time it suggests that application of the principles to a wider range of systems can generate new insights into what is required for successful common pool resource management. At present it appears that interest is focused on local-level common pool resources and, secondarily, on global issues such as climate change. Our study suggests that there is also much to be learned from investigating common pool resource management that takes place at the level of nations. After all, in a world of nation states, this is still the scale at which many, if not most, key decisions are taken.

Responses to this article can be read online at:

http://www.ecologyandsociety.org/issues/responses. php/5319

\section{Acknowledgments:}

This paper is based on research financed by the Bremen International Graduate School for Marine Sciences - Global Changes in the Marine Realm (GLOMAR). We would like to thank Professor Helmuth Lange from the University of Bremen for recommending that we relate the Peruvian anchovy fishery case with Nobel Prize winner Elinor Ostrom's theoretical work, and for challenging us to do so. Historical fishery statistics were kindly provided by M. Bouchón and M. Niquen from the Pelagic Resources Research Department of the Instituto del Mar del Perú (IMARPE). The manuscript was undoubtedly improved with comments from Federico Iriarte and two anonymous reviewers.

\section{LITERATURE CITED}

Anderies, J. M., M. A. Janssen, and E. Ostrom. 2004. A framework to analyze the robustness of social-ecological systems from an institutional perspective. Ecology and Society 9:18. [online] URL: http://www.ecologyandsociety.org/vol9/ iss $1 / \operatorname{art} 18 /$

Agosto, mes de veda. 1965. Pesca XI(1):26.

Aranda, M. 2009a. Developments on fisheries management in Peru: The new individual vessel quota system for the anchoveta fishery. Fisheries Research 96:308-312.
Aranda, M. 2009b. Evolution and state of the art of fishing capacity management in Peru: the case of the anchoveta fishery. Pan-American Journal of Aquatic Sciences 4:146-153.

Arias Schreiber, M. 2012. The evolution of legal instruments and the sustainability of the Peruvian anchovy fishery. Marine Policy 36:78-89. http://dx.doi.org/10.1016/j.marpol.2011.03.010

Arias Schreiber, M., M. Ñiquen, and M. Bouchon. 2011. Coping strategies to deal with environmental variability and extreme climatic events in the Peruvian anchovy fishery. Sustainability 3:823-846. http://dx.doi.org/10.3390/su3060823

Bakun, A., and S. J. Weeks. 2008. The marine ecosystem off Peru: what are the secrets of its fishery productivity and what might its future hold? Progress In Oceanography 79:290-299.

Barange, M., M. Bernal, M. C. Cergole, L. A. Cubillos, G. M. Daskalov, C. L. de Moor, M. De Oliveira, and D. DickeyCollas. 2009. Currents trends in the assessment and management of stocks. Pages 191-255 in D. J. Checkley, J. Alheit, Y. Oozeki, and C. Roy, editors. Climate change and small pelagic fish. Cambridge University Press, Cambridge, Cambridgeshire, UK. http://dx.doi.org/10.1017/ CB09780511596681.011

Beddington, J. R., D. J. Agnew, and C. W. Clark. 2007. Current problems in the management of marine fisheries. Science 316:1713-1716. http://dx.doi.org/10.1126/science.1137362

Bendezú, S. 2008. Concentración de la propiedad de la flota y de plantas de harina de pescado en el Perú. Pesca 95:4-9.

Bermejo, A. 2004. La Flota Anchovetera Vikinga es una Realidad. Pesca 72:3.

Bruns, B. 2007. Community priorities for water rights: some conjectures on assumptions, principles, and programmes. Pages 28-45 in B. van Koppen, M. Giordano, and J. Butterworth, editors. Community-based water law and water resource management reform in developing countries. $\mathrm{CAB}$ International, Wallingford, Oxfordshire, UK. http://dx.doi. org/10.1079/9781845933265.0028

Caravedo, B. 1979. Estado, Pesca y Burguesía 1939-1973. Teoría y Realidad, Lima, Perú.

Castillo, S., and J. Mendo. 1987. Estimation of unregistered Peruvian anchoveta (Engraulis ringens) in official catch statistics, 1951 to 1982 . Pages 109-116 in D. Pauly and I. Tsukayama, editors. The Peruvian anchoveta and its upwelling ecosystem: three decades of change. Deutsche Gesellschaft fuer Technische Zusammenarbeit (GTZ), Eschbom, Federal Republic of Germany; and International Center for Living Aquatic Resources Management (ICLARM), Manila, The Philippines; Instituto del Mar del Perú, Callao, Perú. 
Chavez, F. P., A. Bertrand, R. Guevara-Carrasco, P. Soler, and J. Csirke. 2008. The northern Humboldt current system: brief history, present status and a view towards the future. Progress in Oceanography 79:95-105. http://dx.doi.org/10.1016/j. pocean.2008.10.012

Checkley, D. J., P. Ayón, T. Baumgartner, M. Bernal, J. C. Coetzee, R. Emmett, R. Guevara-Carrasco, L. Hutchings, L. Ibaibarriaga, and H. Nakata. 2009. Habitats. Pages 12-44 in D. J. Checkley, J. Alheit, Y. Oozeki, and C. Roy, editors. Climate change and small pelagic fish. Cambridge University Press, Cambridge, Cambridgeshire, UK. http://dx.doi. org/10.1017/CBO9780511596681.005

Clark, G. W. 1976. The lessons of the Peruvian anchoveta fishery. California Cooperative Oceanic Fisheries Investigations Reports XIX:57-63.

Comisión estudiara implantación de cuotas. 1970b. Pesca XX (3):30.

Congreso de la República del Perú. 1998. Ley N 26920. Ley que exceptúa del requisito de incremento de flota al que se refiere el artículo 24 de la Ley General de Pesca a aquellos armadores que cuenten con embarcaciones de madera de hasta $110 \mathrm{~m}^{3}$. Publicada en el Diario Oficial "El Peruano", $31 \mathrm{de}$ enero de 1998.

Cox, M., G. Arnold, and S. Villamayor Tomas. 2010. A review of design principles for community-based natural resource management. Ecology and Society 15:38 [online]. URL: http:// www.ecologyandsociety.org/vol15/iss4/art38/.

De La Puente, O., J. C. Sueiro, C. Heck, G. Soldi, and S. De La Puente. 2011. La pesquería Peruana de Anchoveta. Universidad Peruana Cayetano Heredia (Lima), Lima, Perú.

Dietz, T., E. Ostrom, and P. C. Stern. 2003. The struggle to govern the commons. Science 302:1907-1912. http://dx.doi. org/10.1126/science.1091015

Doucet, W. F., G. Saetersdal, and I. Vásquez. 1962. La pesca de anchoveta - Estadística de Pesca y esfuerzo en Octubre, Noviembre y Diciembre de 1961. Instituto de Investigación de los Recursos Marinos, Callao, Perú.

FAO. 2010. The state of the world fisheries and aquaculture 2010. FAO Fisheries and Aquaculture Department, Rome, Italy.

Feeny, D., F. Berkes, B. McCay, and J. Acheson. 1990. The Tragedy of the Commons: twenty-two years later. Human Ecology 18:1-19. http://dx.doi.org/10.1007/BF00889070

Fréon, P., M. Bouchon, C. Mullon, C. García, and M. Ñiquen. 2008. Interdecadal variability of anchoveta abundance and overcapacity of the fishery in Peru. Progress In Oceanography 79:401-412. http://dx.doi.org/10.1016/j.pocean.2008.10.011
Ganoza, F., P. Castillo, and D. Marín. 2000. Variaciones estacionales en la distribución y biomasa de anchoveta entre 1983 y 2000. Boletín Instituto del Mar. Perú 19:157-178.

Garcia, X. 2007. Mercado Peruano. Ola de Fusiones. Aqua Septiembre 2007:14-19.

Gobierno del Perú. 1971a. Decreto Ley N 18810. Ley General de Pesquería. Publicado en el Diario Oficial "El Peruano", 26 de marzo de 1971.

Gobierno del Perú. 1971b. Decreto Supremo Nº 011-71-PE. Se aprueba el Reglamento de la Ley General de Pesquería Decreto Ley $\mathrm{N}^{\circ}$ 18810. Publicado en el Diario Oficial "El Peruano", 25 de junio de 1971.

Gobierno del Perú, Ministerio de Pesquería. 2000. Decreto Supremo $\mathrm{N}^{\circ}$ 001-2000-PE. Aprueban el reglamento del Sistema de Seguimiento Satelital de embarcaciones pesqueras nacionales y extranjeras. Publicado en el Diario Oficial "El Peruano", 09 de febrero del 2002.

Gobierno del Perú, Ministerio de Pesquería. 2001. Decreto Supremo N012-2001-PE. Aprueban el Reglamento de la Ley General de Pesca. Publicado en el Diario Oficial "El Peruano", 14 de marzo del 2001.

Gobierno del Perú, Ministerio de la Producción. $2006 a$. Decreto Supremo $\mathrm{N}^{\circ}$ 024-2006-PRODUCE. Modifican artículo $45^{\circ}$ del Reglamento de la Ley General de Pesca y dictan disposición para favorecer la financiación de proyectos de investigación científica, desarrollo tecnológico y otros vinculados a la pesquería y acuicultura. Publicado en el Diario Oficial "El Peruano", 26 de noviembre del 2006.

Gobierno del Perú, Ministerio de la Producción. $2006 b$. Resolución Ministerial N 215-2006-PRODDUCE: Constituyen Comisión Especial para evaluar y plantear soluciones al exceso de esfuerzo pesquero en la explotación de la pesquería industrial de la especie anchoveta. Publicada en el Diario Oficial "El Peruano", 24 de agosto del 2006.

Gobierno del Perú, Ministerio de la Producción del Perú. 2008. ¡Revolución en la pesca!: Ponen orden para evitar depredación de nuestro mar. PRODUCE 1:28-33.

Hammergren, L. 1981. Peruvian political and administrative responses to El Niño. Pages 317-350 in M. H. Glantz and J. D. Thompson, editors. Resource management and environmental uncertainty: lessons from coastal upwelling fisheries. John Wiley and Sons, New York, New York, USA.

Hanna, S., C. Folke, and K.-G. Maler. 1995. Property rights and environmental resources. Pages 15-29 in S. Hanna and M. Munasinghe, editors. Property rights and the environment: social and ecological issues. The World Bank, Washington, D.C., USA. 
Hardin, G. 1968. The tragedy of the commons. Science 162:1243-1248. http://dx.doi.org/10.1126/science.162.3859.1243

Ibarra, A. A., C. Reid, and A. Thorpe. 2000. The political economy of marine fisheries development in Peru, Chile and Mexico. Journal of Latin American Studies 32:503-527. http:// dx.doi.org/10.1017/S0022216X00005824

IMARPE. 1965. La Pesquería de la anchoveta. Informe Nro. 1. Instituto del Mar del Perú, La Punta, Callao, Perú.

Marcación de 200,000 anchovetas en Chimbote, Callao, Pisco e Ilo. 1970a. Pesca XXI(3):16-18.

Mondoux, S., T. Pitcher, and D. Pauly. 2008. Ranking maritime countries by the sustainability of their fisheries. Pages 13-27 in J. Alder and D. Pauly, editors. A comparative assessment of biodiversity, fisheries and aquaculture in 53 countries' Exclusive Economic Zones. Fisheries Centre, University of British Columbia, Vancouver, British Columbia, Canada.

Mullon, C., P. Fréon, and P. Cury. 2005. The dynamics of collapse in world fisheries. Fish and Fisheries 6:111-120. http://dx.doi.org/10.1111/j.1467-2979.2005.00181.x

Neiland, A. E. 2006. Incorporating common pool resource (CPR) issues into fisheries management in developing countries: key lessons and best practice. IDDRA Ltd., Portsmouth, Hampshire, UK.

Número Equivocado, 14228. 1962a. Pesca V(5):33.

Ostrom, E. 1990. Governing the commons. Cambridge University Press, Cambridge, Cambridgeshire, UK. http://dx. doi.org/10.1017/CBO9780511807763

Ostrom, E. 2009a. Design principles of robust property-rights institutions: what have we learned? Pages 25-51 in G. K. Ingram and Y.-H. Hong, editors. Property rights and land policies. Lincoln Institute of Land Policy, Cambridge, Maine, USA.

Ostrom, E. 2009b. The contribution of community institutions to environmental problem-solving. Pages 87-112 in A. Breton, B. G., S. Dalmazzone, and G. Garrone, editors. Governing the environment: salient institutional issues. Edward Elgar, Cheltenham, Gloucestershire, UK.

Ostrom, E., J. Burger, C. B. Field, R. B. Norgaard, and D. Policansky. 1999. Revisiting the commons: local lessons, global challenges. Science 284:278-282. http://dx.doi. org/10.1126/science.284.5412.278

Pauly, D., J. Alder, E. Bennett, V. Christensen, P. Tyedmers, and R. Watson. 2003. The future for fisheries. Science 302:1359-1361. http://dx.doi.org/10.1126/science.1088667

Perú ratifica el acuerdo de París. 1961. Pesca II(1):38-39.

Regalo de Pascua: nuevo impuesto. 1962b. Pesca V(6):60.
Roemer, M. 1970. Fishing for growth, export-led development in Peru, 1950-1967. Harvard University Press, Cambridge, Maine, USA.

SNP. 2010. Memoria Anual 2010. Sociedad Nacional de Pesqueria, Lima, Perú. [online]. URL: http://snp.org.pe/wp/ wp-content/uploads/2011/06/MemoriaSNP.pdf.

Thorp, R., and G. Bertran. 1978. Perú: 1890-1977. Crecimiento y Políticas en una economía abierta. Columbia University Press, New York, New York, USA.

Thorpe, A., A. A. Ibarra, and C. Reid. 2000. The new economic model and marine fisheries development in Latin America. World Development 28:1689-1702. http://dx.doi.org/10.1016/ $\underline{\text { S0305-750X(00)00045-0 }}$

Tsukayama, I., and M. L. D. Palomares. 1987. Monthly catch and catch composition of Peruvian anchoveta (Engraulis ringens) (northern-central stock). Pages 89-108 in D. Pauly and I. Tsukayama, editors. The Peruvian anchoveta and its upwelling ecosystem: three decades of change. Deutsche Gesellschaft fuer Technische Zusammenarbeit (GTZ), Eschbom, Federal Republic of Germany; and International Center for Living Aquatic Resources Management (ICLARM), Manila, The Philippines; Instiuto del Mar del Perú, Callao, Perú. 
APPENDIX 1. List of interviewees:

From The Vice-Ministry of Fisheries:

1. Director General of Fish Extraction and Processing

2. Sub director of Fish for Human Consumption

3. Sub director of indirect Human Consumption

4. Head of the Vice -Ministry Data Base Office

5. Ex-Director General of Fish Extraction and Processing

6. Director General of Monitoring, Control and Surveillance

7. Director of Inspection and Auditing

8. Director of Monitoring, Infringements and Penalties

9. Head of Satellite Tracking System Office

10. Advisor to the Marine Fisheries Control and Surveillance Program

From the Peruvian Marine Research Institute (IMARPE):

1. Executive Director

2. Advisor to the Executive Director

3. Scientific Director

4. Advisor to the Scientific Director

5. Director de of Pelagic Resources, Neritic and Oceanic Resources Research Department

6. Head of Trans-zonal and Highly Migratory Resources Research Unit

7. Head of the Population Dynamics Research Unit

8. Head of IMARPE's Coastal Laboratories

From the fishing private sector

1. General Manager of the National Fisheries Society (SNP)

2. Head of the Office of Economics and Fisheries Statistics (SNP)

3. Head of Office of Environmental Affairs (SNP)

4. SNP's member at IMARPE's Directorate Council

5. Ex-President of PESCA PERU

6. Director of Fleet and Supplies - Fishing Company Pesquera Hayduk S.A.

7. Director of Research Planning and Development - Fishing Company Pesquera Diamante S.A.

8. Head of Fleet Department - Fishing Company CFG Investment S.A.C.

9. Fleet operator - Fishing Company Pesquera Austral 
APPENDIX 2. Format of semi-structured interviews (page 1 of 2)

Date:

Name:

Current position/job:

Previous positions/jobs:

How long have you been involved with Peruvian fisheries management/ research/ industry/ business?

How long with the anchovy fishery?

Can you tell me which major differences do you remember regarding the following topics (see below) between the 1960s (if applicable), 70s (if applicable), 80s (if applicable), 90s (if applicable) and nowadays?

When and why you think that the things (related to each topic) changed?

Topics:

- Formal and informal difficulties for new companies to join the fishery

- Formal and informal difficulties for the entrance of new vessels to the fishery

- Anchovy fishery licenses

- Knowledge of anchovy fishing stocks, monitoring and survey techniques

- Geographical distribution of the northern-central anchovy stock

- Rule enforcement and sanctions

- Payments of fishing licenses, permits, taxes, other.

- Relations between the fishing industry, the government and the Peruvian Marine Research Institute (IMARPE)

Which were the main sources of conflicts among the fishing companies during the 1960s (if applicable), 70s (if applicable), 80s (if applicable), 90s (if applicable)? How were these conflicts resolved or not?

Which are the main sources of conflicts among the fishing companies nowadays? How are these conflicts resolved or not? 
APPENDIX 2. Format of semi-structured interviews (page 2 of 2)

Which were the main sources of conflicts between the fishing companies and the government (including IMARPE) during the 1960s (if applicable), 70s (if applicable), 80s (if applicable), 90s (if applicable)? How were these conflicts resolved or not?

Which are the main sources of conflicts between the fishing companies and the government (including IMARPE) nowadays? How are these conflicts resolved or not?

Why do you think that anchovy landings have been relatively stable during the last two decades? Why has the anchovy fishery not collapsed like it happened during the early 70s? 